\title{
Effects of Participation in Activities Organized by the Sarong Conservation Club on Islamic Behavior of Youth in Ban Sarong, Khao Tum Sub-district, Yarang District, Pattani Province
}

\author{
Kasetchai Laeheem ${ }^{1}$ \\ ${ }^{1}$ Faculty of Liberal Arts, Prince of Songkla University, Hatyai, Thailand \\ Correspondence: Kasetchai Laeheem, Faculty of Liberal Arts, Prince of Songkla University, Hatyai, Songkhla, \\ 90110, Thailand. E-mail: Lkasetchai@yahoo.com
}

Received: August 19, 2014

Accepted: October 31, 2014 Online Published: February 12, 2015

doi:10.5539/ass.v11n5p58

URL: http://dx.doi.org/10.5539/ass.v11n5p58

\begin{abstract}
The study aimed to investigate the effects of participation in activities organized by the Sarong Conservation Club on Islamic behavior of youth in Ban Sarong, Khao Tum Sub-district, Yarang District, Pattani Province. The study applied a true control group pretest and posttest design with 70 youths selected using purposive sampling from youths with low and high scores obtained from answering questions in an Islamic behavioral appraisal instrument. The youths were divided into an experimental group consisting of 35 youths who participated in activities organized by the Sarong Conservation Club (youths with low scores) and a control group consisting of 35 youths who participated in religious activities organized by the mosque (youths with high scores). The experiment was performed according to plan from January 2014 to July 2014. The data were analyzed using independent samples t-test and paired samples t-test.

The results of the study revealed that prior to participation the experimental group who participated in activities organized by the Sarong Conservation Club had Islamic behavior at a level that was significantly lower than the control group who participated in religious activities organized by the mosque at the level of .001. However, after participating in activities organized by the Sarong Conservation Club, the experimental group had a significantly higher level of Islamic behavior than the control group at .01. The youths in the experimental group who participated in activities organized by the Sarong Conservation Club, and those in the control group who participated in religious activities organized by the mosque had Islamic behavior at a significantly higher level than before their participation in the activities at .001 .
\end{abstract}

Keywords: activities organized, religious activities organized, Islamic behaviors, sarong conservation club

\section{Introduction}

Islam specifies the way of life in the Quran for all Muslims to strictly follow, and for them to take the prophet Muhammad as an exemplary model. Muslims must follow the Five Pillars, the Six Articles of Faith, and Islamic ethics and morals. In the past, most Muslims led their life in accordance with expectations of Muslim society and with Islamic principles and strictly practice religious activities. However, nowadays only a minority of youths follow that way of life while the majority of them lead their life in conflict with expectations of Muslim society and Islamic principles. This is a social problem that all parties concerned need to join hands to solve. One of the important causes of the problem stems from social changes as a result of rapid technological advancement that affects Muslim youth directly and indirectly in terms of their mental and living conditions (Anmunajid, 2004; Laeheem \& Baka, 2010). Some Muslim youth neglect practice religious activities and hence, their lives are deviated from religious principles, and they give importance to the way of life that is in conflict with religious principles. They indulge in entertainment and wrong values of modern societies without paying attention to righteousness and warnings from people around them. For example, they do not dress according to religious principles, have boyfriends or girlfriends, are involved in drugs and gambling; go to night life entertainment places; are sexually deviated; have premarital sexual relationships, do not prey, and do not fast, etc. These have become chronic problems found in Thai society (Anmunajid, 2004; Annadwee, 2004; Mahama, 2009; Laeheem \& Baka, 2010). 
It can be seen that Muslim youths now have more freedom in the modern world of globalization so much so that they do not behave in accordance with religious principles. They express their feeling based on their zeal for something that is challenging, exotic, new, modern, and fashionable according to influence of media and their peers. As a result, Muslim youth openly commit sin and other behaviors forbidden by Islam, and such behaviors become habitual and customary, and these youths become shameless, and uninterested in religious practice (Anmunajid, 2004; Laeheem \& Baka, 2010). A study on Islamic behaviors among youth in the three Southern border provinces found that 68.3 percent of Thai Muslim youth did not behave according to the Islamic way of life (Laeheem, 2014), and 63.5 percent were not cared for the Islamic way of life (Laeheem, 2013a). Therefore, it is necessary to find ways to solve and prevent the problems, and to promote the Islamic way of life among Muslim youth by focusing on the training and warning process, and on encouraging them to be steadfast in Islamic principles (Baka, 2007; Laeheem \& Baka, 2010). Socialization should be conducted for youth to hold on to good deeds, morals, ethics, to have awareness of right and wrong, to behave in the right way, to be determined to live the Islamic way of life and in accordance with the social norms (Boonyasith, 1988; Khagphong, 2004; Mahama, 2009; Laeheem \& Baka, 2010).

One approach that is used to promote youth's Islamic behavior is to establish a "Village Youth Club" with youths as the core to drive the operations of the club. The club should have an administrative structure, assignments of roles and responsibilities, and a definite plan of activities to be organized. Religious leaders and community leaders should participate in the advisory board of the club to play a role in providing close supervision. It is important to place emphasis on activities or projects that incorporate religious and social parts, and correspond with youth's needs. The activities or projects must focus on benefits for the community and must be in line with Islamic principles. Such activities include providing knowledge, managing teaching and learning activities, organizing training courses, providing warnings, persuading, providing advice, and organizing practice sessions, etc. Financial support could be from Zakat, organizing fundraising activities such as inviting donations during prayer times on Fridays, organizing tea parties or Khao Yam (a local dish of mixed fresh vegetables and rice) parties, selling clothes, organizing a weekly flea market at the mosque and rent out areas for sellers to set up their stalls, and selling books and VCDs on the religion. In addition, letters requesting financial assistance should be sent to different private and government organizations such as Tambon Administrative Organizations, Provincial Administrative Organization, municipal councils, factories, business places, shops and other organizations (Laeheem, 2013b).

To solve the abovementioned problems, it is necessary to conduct a study on the effects of participation in activities organized by the Sarong Conservation Club on Islamic behavior of youth in Ban Sarong, Khao Tum Sub-district, Yarang District, Pattani Province to find out whether or not youths who participate in activities organized by the Sarong Conservation Club had a higher level of Islamic behavior, and how. The results of this study will be useful as guidelines for promoting and supporting youth to behave in the Islamic way and for preventing youth from behaving against the Islamic principles. Moreover, it will be useful in helping Muslim youth who behave against Islamic principles to have Islamic behaviors before the problem becomes more severe and becomes a social problem that is difficult to solve. In addition, related organizations would be able to help solve the problem timely.

\section{Methods}

\subsection{Target Group}

The target group for this study was a group of 70 youths in Ban Sarong, Khao Tum Sub-district, Yarang District, Pattani Province. This group was divided into two groups. One was an experimental group consisting of 35 youths who participated in activities organized by the Sarong Conservation Club and who received low scores from doing an Islamic behavioral appraisal instrument. The other group was a control group consisting of 35 youths who participated in religious activities organized by the mosque that had high scores from doing an Islamic behavioral appraisal instrument. These two groups of subjects were selected using specific sampling from low and high scores, and they were willing to participate in the activities for this study.

\subsection{Research Instruments and Development of the Instruments}

1) An Islamic behavioral appraisal instrument developed by the researchers. This instrument was for youth to do self-assessment on their behaviors during the previous year. In doing the self-assessment test, they had to specify the level of their behaviors. The instrument consisted of 20 questions, and there were two types of questions. The first type was positive questions consisting of 12 items on behaviors such as praying five times a day, fasting during the Ramadan month, performing donations (Zakat), reading the Quran, and mentioning/remembering Allah (Zikir), etc. The scale was from never "0"; occasionally, "1"; sometimes "2"; often "3"; to always " 4 ". The 
second type was negative questions consisting of eight items on behaviors such as football betting; smoking; drinking; going to Karaoke clubs, discotheques, pubs; and using drugs, etc. The scale was from never "4"; occasionally "3"; sometimes "2"; often "1"; to always "0" (Laeheem, Baka, Tahe, \& Walee, 2011; Laeheem, 2014).

2) Activities organized by the Sarong Conservation Club. The activities were developed by the researchers (Laeheem, Baka, Tahe, \& Walee, 2011; Laeheem, 2013) who conducted an operational research to promote Islamic behaviors among youth in the three Southern border provinces which was a case study of Ban Sarong, Khao Tum Sub-district, Yarang District, Pattani Province from January 2014 to July 2014 totaling 6 months.

3) Religious activities organized by the mosque. The activities were to promote Islamic behavior as designated and organized by religious leaders and the Ban Sarong Mosque Committee for a period of six months from January 2014 to July 2014. The activities included admonitions after praying, listening to weekly sermons, attending Islamic ethics training, learning the Quran, learning about the religion and community development, etc.

\subsection{Experimental Design}

This is a true experimental research with an experimental group participating in activities organized by the Sarong Conservation Club, and a control group participating in religious activities organized by the mosque. The study employed true control group, pretest-posttest design (Campbell \& Rosso, 1999).

\subsection{Data Collection}

The experiment was performed with the experimental group that participated in activities organized by the Sarong Conservation Club, and the control group that participated in activities organized by the mosque. The activities that both groups participated were organized and managed according to the plans of the Sarong Conservation Club, and the Ban Sarong Mosque Committee for a period of six months from January 2014 to July 2014. Before the experiment, the researcher assessed the levels of Islamic behavior of the experimental and control groups using an Islamic behavioral appraisal instrument and marked the test, and after the 6-month experiment, the assessment and marking were performed again for both groups.

\subsection{Data Analysis}

The data were analyzed with the R Program to compare Islamic behavior between the experimental and the control groups using independent samples t-test while comparisons of Islamic behavior between the experimental group and the control group before and after their participation in the activities using paired samples t-test.

\section{Results}

The youths who participated in activities organized by the Sarong Conservation Club (the experimental group) and those participating in religious activities organized by the mosque (the control group) were different in their Islamic behavior at a statistically significant level of .001. Before the experiment, the youths in the experimental group who participated in activities organized by the Sarong Conservation Club had a lower level of Islamic behavior (at the average of 2.19) than those in the control group who participated in religious activities organized by the mosque whose average value was 3.31 . The difference of the averages was -1.12 (95\% Confidence Interval: C.I. was $-1.29,-0.96)$ as shown in Table 1.

Table 1. Islamic way behavior before participating in the project

\begin{tabular}{ccccccc}
\hline Group & $\begin{array}{c}\text { Mean } \\
\text { Score }\end{array}$ & S.D. & $\mathrm{n}$ & $\begin{array}{c}\text { Mean of the differences } \\
(95 \% \text { C.I. })\end{array}$ & t-test & $p$-value \\
\hline Experimental group & 2.19 & 0.26 & 35 & $-1.12(-1.29,-0.96)$ & $13.915^{* * *}$ & 0.000 \\
Control group & 3.31 & 0.40 & 35 & &
\end{tabular}

$* * * \mathrm{P}<.001$

After the experiment, the youths who participated in religious activities of the mosque (the control group) had Islamic behaviors at the level 3.67, which was higher than that before the experiment (at the average of 3.31). The difference was statistically significant at the level of .001; the difference between the averages was $0.36(95 \%$ C.I. was $0.23,0.49$ ) as shown in Table 2. 
Table 2. Islamic way behavior of control group before and after participating in the project

\begin{tabular}{ccccccc}
\hline Control group & $\begin{array}{c}\text { Mean } \\
\text { Score }\end{array}$ & S.D. & $\mathrm{n}$ & $\begin{array}{c}\text { Mean of the differences } \\
(95 \% \text { C.I. })\end{array}$ & t-test & $p$-value \\
\hline After participating & 3.67 & 0.14 & 35 & $0.36(0.23,0.49)$ & $5.700^{* * *}$ & 0.000 \\
Before participating & 3.31 & 0.40 & 35 & &
\end{tabular}

$* * * \mathrm{P}<.001$

After the experiment, the youths who participated in activities of the Sarong Conservation Club had Islamic behavior at the average level of 3.77, which was higher than that before the experiment at the average level of 2.18. The difference was statistically significant at the level of .001; the difference between the averages was $1.59(95 \%$ C.I. was $1.48,1.69)$ as shown in Table 3.

Table 3. Islamic way behavior of experimental group before and after participating in the project

\begin{tabular}{ccccccc}
\hline Experimental group & $\begin{array}{c}\text { Mean } \\
\text { Score }\end{array}$ & S.D. & $\mathrm{n}$ & $\begin{array}{c}\text { Mean of the differences } \\
(95 \% \text { C.I. })\end{array}$ & t-test & $p$-value \\
\hline After participating & 3.77 & 0.11 & 35 & $1.59(1.48,1.69)$ & $29.977^{* * *}$ & 0.000 \\
Before participating & 2.18 & 0.25 & 35 & &
\end{tabular}

$* * * \mathrm{P}<.001$

After the experiment, the youths who participated in activities organized by the Sarong Conservation Club (the experimental group) and those participating in religious activities organized by the mosque (the control group) were different in their Islamic behavior at a statistically significant level of .01 . The average value for the experimental group who participated in activities of the Sarong Conservation Club was 3.77. After the experiment, the experimental group had a higher level of Islamic behavior than those participating in activities of the mosque at the average value of 3.67. The difference of the averages was $0.10(95 \%$ C.I. was $0.03,0.16)$ as shown in Table 4.

Table 4. Islamic way behavior after participating in the project

\begin{tabular}{ccccccc}
\hline Group & $\begin{array}{c}\text { Mean } \\
\text { Score }\end{array}$ & S.D. & $\mathrm{n}$ & $\begin{array}{c}\text { Mean of the differences } \\
(95 \% \text { C.I. })\end{array}$ & t-test & $p$-value \\
\hline Experimental group & 3.77 & 0.11 & 35 & $0.10(0.03,0.16)$ & $3.129^{* *}$ & 0.003 \\
Control group & 3.67 & 0.15 & 35 & &
\end{tabular}

$* * \mathrm{P}<.01$

\section{Discussion and Conclusions}

The results of the study revealed significant findings that participation in activities organized by the Sarong Conservation Club, and those organized by the mosque could promote Islamic behavior among youth. In other words, both types of activities were effective. Before the experiment, the youths in the experimental group who participated in activities of the Sarong Conservation Club had a lower level of Islamic behavior than those in the control group who participated in activities of the mosque. However, after the experiment, the youths in the experimental group who participated in activities of the Sarong Conservation Club had a higher level of Islamic behavior than those in the control group who participated in activities of the mosque. Nevertheless, after the experiment, both groups of youth had a higher level of Islamic behavior than before the experiment. Therefore, it is noticeable that participation in the activities organized by the Sarong Conservation Club could promote a higher level of Islamic behavior than that in activities organized by the mosque. This is a confirmation that participation in activities of the Sarong Conservation Club can promote Islamic behavior and solve the problem of youth whose behaviors are not in accordance with Islamic principles, and can do it better than religious activities of the mosque. This is because the activities organized by the Sarong Conservation Club developed by Laeheem (2013) were activities that look after youth according to Islamic principles in order to promote and support youth to acquire Islamic behavior by establishing a "Village Youth Club". Setting up a village youth club is one way to prevent the problem of youth behaving in conflict with religious principles, and to enable 
them to behave more in accordance with Islamic principles. It is a model that promotes youth to systematically participate in the operation and administration of the club in managing and taking care of their fellow youths. Moreover, it promotes teamwork among youth and other related organizations and individuals to work in an integrated way which is in congruence with a claim made by some researchers that successful operation of activities means the importance given to interactions, designation of structure and clear assignments of responsibilities (Mapobsuk, 2000; Tansakul, 2004; Spector, 2006; DeLamater \& Myyers, 2007). Operations of activities with emphasis on youth participation in all steps from thinking, planning, decision-making, implementing, and evaluating are opportunities for youth to participate in decision-making from the first step to the last step. Voluntary participation is an important factor that enables the operation to successfully achieve the goals that have been set (Keawhawong, 1999; Patanapongsa, 2004; Bureekul, 2005). Such participation can result in more youths with Islamic behaviors. Many academics found in their studies that prevention of misbehavior and promotion of desirable behavior require various approaches and operations. Moreover, there needs to be a clear management system and cooperation from related organizations, individuals from all parts of society, a correct method of youth socialization, especially a method with religious principles as its core, and adult role models (Committee of Education, Religion, Art and Culture, 2003; Chareonwongsak, 2006).

In addition, the results of this study illustrate that participation in activities of the Sarong Conservation Club that focuses on and attaches importance to activities related to mental socialization and training with Islamic principles as the main part is to instill in young people correct awareness that gives them realization of importance of Islamic behavior. Popenoe (1993), Adivatanasit (2002), Thitiwattana (2004), and Laeheem (2013) specify that participation in activities that emphasize religious principles to give understanding, warning, and to change youth's behavior is one process that can be used in transferring knowledge, ideas, attitudes, ideologies, cultures and personalities that can shape youth the way society desires. Furthermore, participation in such activities can change their misbehavior and unreligious behavior to behavior that is in line with social order and norms, which is a process that can develop youth to be well disciplined and to behave according to social norms, and to live in society happily with others. Narongraksakhet (1997), Thepsitha (1998), and Mahama (2009) agree that using religious principles in developing, correcting and preventing youth from misbehavior so that they behave in desirable ways is a most suitable method. The reason is that using religious principles in training, refining, and socializing youth is to provide them with moral support and enable them to be ethical persons who live a disciplined life. This is in agreement with Amarin (2000), Lhamlert (2009), and Ritnetikul (2009) who state that participating in activities that correspond with youth's needs and interest can enable them to apply the substances of activities in self-improvement by changing their own behavior in a good and desirable way that provides hands-on experience. The Department of Mental Health (2000) and Chatsupakul (2003) specify that activities that emphasize religious principles and participants' needs is a way to develop youth. Such activities enhance their emotional and social development, change their habits and personalities, improve their social adjustment and social skills, help them to be expressive, to be responsible for their duties, to respect their own and others rights, to comply with rules and regulations and social norms. Khagphong (2004), Mahama (2009), and Laeheem \& Baka (2010) claim that activities that focus on Islamic principles can prevent Muslim youth from many problems because knowledge of Islamic principles can prevent Muslim youth from being misled by the environments and social trends. Thus, Muslim youth who have Islamic behavior are usually those who have knowledge and understanding of Islamic principles, and strict religious practice because they have been instilled with Islamic morals and ethics. Therefore, participation in Islamic activities and training is significantly associated with Islamic behaviors. Youth who regularly and those who occasionally participate in Islamic activities and training have more opportunities than those who never participate in such activities (Laeheem, 2013). Furthermore, participation in activities that develop youth's potential and focus on Islamic principles of morals and ethics can promote Islamic behavior in youth (Laeheem \& Baka, 2012).

The results of the study can help individuals and organizations that are related to promoting youth to have Islamic behavior to use in forming good policies and concrete strategies for promotion and support Islamic behavior among youth. In particular, Islamic, and governmental organizations, in forming policy, should include them in instilling in youth the awareness in leading their lives the Islamic way and take the Prophet Muhammad as their role model. Additionally, they can include them in the policy on promotion and development of the family institution so that it is strong and are able to look after children in order to lead their lives based on Islamic principles, etc. Besides, related individuals and organizations should provide assistance to youth who have risk behavior or behavior that is not in accordance with Islamic principles using socialization in the Islamic way. This includes encouraging youth to strictly practice their religion; providing them with knowledge and understanding of the teaching of Islam; raising them the Islamic way, encouraging them to participate in Islamic 
activities and training, etc. The results of this study show that the mentioned method can enable Muslim youth to be brought up the Islamic way so that youth will eventually have Islamic behavior.

\section{Acknowledgements}

This work was supported by the Higher Education Research Promotion and National Research University Project of Thailand, Office of the Higher Education Commission.

\section{References}

Adivatanasit, C. (2002). Buddhist sociology. Bangkok: Mahachulalongkornrajavidyalaya.

Amarin, T. (2000). The study of the nurturance of mathayom suksa IV students of Mahidol witthayanusorn school in changwat Nakhonpathom (Unpublished master's thesis). Srinakharinwirot University, Bangkok, Thailand.

Anmunajid, S. (2004). Prohibited relationships. Retrieved February 19, 2012, from http://www.majlis-ilmi.org/ islam $/$ modules.php?op=modload\&name=Sections\&file=index\&req=viewarticle\&artid $=1 \&$ page $=1$

Annadwee, A. (2004). Dear Muslim intellectuals. Retrieved February 19, 2012, from http://www.majlis-ilmi. org/slam $/$ modules.php?op=modload\&name=Sections \& file=index\&req=viewarticle\&artid $=8 \&$ page $=1$

Baka, D. (2007). Masjid: Economic basic and cultural capital. Pattani: Prince of Songkla University.

Boonyasith, A. (1988). The role of Islamic leaders in solving the crime problem in the three southern border provinces (Unpublished master's thesis). Srinakharinwirot University, Bangkok, Thailand.

Bureekul, T. (2005). Participation theories and processes. Nonthaburi: King Prajadhipok's Institute.

Cambell, D. T., \& Russo, M. J. (1999). Social Experimentation. London: Sage. Weely-Manager.

Chareonwongsak, K. (2006). Intervention and preventing the students' violence behavior. Retrieved January 11, 2010, from http://www.kriengsak.com/index.php?components=content\&id_content_category_main=23\&id _content_topic_main $=53 \&$ id_content_management_main $=908$

Chatrasupakul, K. (2003). Group Activity in School (5th ed.). Bangkok: Pattanasuksa.

Committee of Education, Religion, Art and Culture. (2003). Report summarizes the problems of the students' controversy and violence. Bangkok: the Senate.

DeLamater, J. D., \& Myyers, D. J. (2007). Social Psychology (6th ed.). Belmont, CA: Tomson/ Wadsworth.

Department of Mental Health. (2000). The activities manual to enhance life skills for children. Nontaburi: Office of Mental Health Development.

Kaewhawong, T. (1999). The strengthening process of strong communities. khonkaen: Klangnanawittaya.

Khagphong, P. (2004). Islamic faith on behavior of child breeding of Thai Muslim family in Bangkok (Unpublished master's thesis). Prince of Songkla University, Pattani, Thailand.

Laeheem, K., \& Baka, D. (2012). A study of youths' violence behaviors in the three southern border provinces of Thailand. NIDA Journal, 52(1), 159-187.

Laeheem, K. (2013a). Reception of behavior supervision based on Islamic belief among Muslim adolescents in the three southern-border provinces, Thailand. Kasetsart Journal: Social Sciences, 34(2), 323-334.

Laeheem, K. (2013b). The Islamic way of youth care by Muslim leaders in the three southern-border provinces of Thailand. Asian Social Science, 9(10), 160-168. http://dx.doi.org/10.5539/ass.v9n10p160

Laeheem, K. (2014). Factors associated to Islamic behavior among Thai Muslim youth in the three southern border provinces, Thailand. Kasetsart Journal: Social Sceinces, 35(2) (in press).

Laeheem, K., \& Baka, D. (2010). A Study of the Thai Muslim Youth's Way of Life to Maintaining Peace in the Three Southern Border Provinces of Thailand. Songklanakarin Journal of Social Sciences \& Humanities, 16(6), 973-988.

Laeheem, K., Baka, D., Tahe, H., \& Walee, S. (2012). The roles of Muslim leaders for adolescents supervision on Islamic way to maintaining peace in the southern border provinces of Thailand. Songkhla: Prince of Songkla University.

Lhamlert, S. (2009). A study of aggressive behavior and self-controlled program development to reduce aggressivebBehavior of female juveniles (Unpublished master's thesis). Srinakharinwirot University, Bangkok, Thailand. 
Mahama, M. (2009). Islam: Way of life. Songkhla: Po-bard.

Mapobsuk, W. (2000). Human relations. Bangkok: Se-Eduaction.

Narongraksakhet, I. (1997). History of Islamic education. Pattani: College of Islamic studies, Prince of Songkla University.

Patanapongsa, N. (2004). Participation: Basic principles, techniques and case studies. Chiang Mai: Chiang Mai University.

Popenoe, D. (1993). Sociology. Englewood Cliffs, N.J.: Prentice-Hall.

Ritnetikul, C. (2009). The effect of group activities on attitude toward value of virginity of female students (Unpublished master's thesis). Srinakharinwirot University, Bangkok, Thailand

Spector, E. (2006). Industrial organizational psychology: Research and practice (4th ed.). New York: Willey

Tansakul, P. (2004). Why teams do not work. Bangkok: Jit Jakawarn.

Thepsitha, S. (1998). Social control. Bangkok: The National Council on Social Welfare of Thailand.

Thitiwattana, P. (2004). Human and sociology. Bangkok: Kasetsart University.

\section{Copyrights}

Copyright for this article is retained by the author(s), with first publication rights granted to the journal.

This is an open-access article distributed under the terms and conditions of the Creative Commons Attribution license (http://creativecommons.org/licenses/by/3.0/). 